\title{
Vector Competence of Argentine Mosquitoes (Diptera: Culicidae) for West Nile virus (Flaviviridae: Flavivirus)
}

\author{
MARÍA V. MICIELI ${ }^{1}$, AMY C. MATACCHIERO ${ }^{2}$, EVANGELINA MUTTIS ${ }^{1}$, DINA M. FONSECA ${ }^{3}$, \\ MATTHEW T. ALIOTA ${ }^{2}$, and LAURA D. KRAMER $2,4,5$ \\ ${ }^{1}$ Centro de Estudios Parasitológicos y de Vectores (CONICETCCT-La Plata, Universidad \\ Nacional de La Plata). Calle 2 No 584, 1900, La Plata, Argentina. \\ ${ }^{2}$ New York State Department of Health, Wadsworth Center, 5668 State Farm Rd., Slingerlands, \\ NY 12159. \\ ${ }^{3}$ Center for Vector Biology, Rutgers University, 180 Jones Ave., New Brunswick, NJ 08901. \\ ${ }^{4}$ School of Public Health, State University of New York at Albany, Department of Biomedical \\ Sciences, Center for Medical Sciences, P.O. Box 22002, Albany, NY 12201-02002.
}

\begin{abstract}
We examined the ability of Culex pipiens L. complex mosquitoes from Argentina to vector West Nile virus (WNV) to assess their role in the transmission of WNV in South America. Several egg rafts of Culex spp. were collected from different breeding sites in the suburbs of the city of La Plata, Argentina, and a subset of each progeny was scored with morphological and genetic species indicators. Surprisingly, we did not find $C x$. pipiens form pipiens, but found evidence of genetic hybrids of Culex quinquefasciatus and Cx. pipiens f. molestus. We then used morphological traits to create two colonies predominantly composed of one of these two taxa, although some hybrids are likely to have been included in both. These colonies were used in vector competence studies using NY99 and WN02 genotype strains of WNV obtained in New York State. As controls, we also tested colonies of U.S. Cx. quinquefasciatus and Cx. pipiens f. molestus. Additional Culex larvae from three drainage ditches near the cities of La Plata and Berisso, Argentina, were identified by morphological and high-resolution molecular markers (microsatellites) as $C x$. quinquefasciatus Say, Cx. pipiens form molestus, and hybrids. Results indicate that Argentinian Culex are competent but only moderately efficient vectors of WNV and are less susceptible to this virus than comparable U.S. mosquito strains. Studies of vertical transmission of NY99 virus by Cx. pipiens f. molestus hybrids from Argentina yielded a minimal filial infection rate of 1.19 from females feeding during their second and later bloodmeals.
\end{abstract}

\section{Keywords}

Culicidae; mosquitoes; arbovirus; West Nile virus; vector competence

\footnotetext{
West Nile virus (WNV; Flaviviridae: Flavivirus) is a zoonotic pathogen, maintained in an enzootic cycle where it is transmitted between ornithophilic mosquitoes and avian hosts, but the virus also infects humans, equines, and many other vertebrates. WNV was first isolated from a febrile woman in Uganda in 1937 (Smithburn et al. 1940) and subsequently was identified as the etiologic agent of sporadic cases and major outbreaks in Africa, Europe,
}

(C) 2013 Entomological Society of America

${ }^{5}$ Corresponding author, kramer@wadsworth.org.. 
Asia, Australia, and the Middle East. Following a single introduction into the United States in 1999 (Lanciotti et al. 1999), WNV rapidly expanded its range in a step-wise fashion and by 2004 was well established in North America and portions of Canada to the north (Kramer et al. 2007). Infection leads to a broad spectrum of disease ranging from fever to severe neurologic disease including meningitis, encephalitis, and acute flaccid paralysis. Severe disease is more common in older individuals, and immunocompromised hosts are at particular risk. The largest epidemics of West Nile neuroinvasive disease (WNND) in the United States and the world occurred in 2003 (2,866 cases of encephalitis, and 264 deaths) and 2012 in the United States when 2,873 cases were classified as neuroinvasive disease with 286 deaths (Centers for Disease Control and Prevention [CDC] 2012). Since 1999, an estimated 3.3 million people in the United States have been infected with WNV. This disease has also been noted in Puerto Rico, Cuba, and Argentina in addition to the continental United States and Canada in the western hemisphere (Dupuis et al. 2005, Morales et al. 2006).

The first isolation of WNV in South America was recorded in Argentina in February 2006 when it was isolated from the brains of three horses that died from encephalitis. The horses were from different farms in central Argentina (Morales et al. 2006). Phylogenetic analysis of NS5 fragments of the Argentinean viruses placed them in the North American cluster, lineage IA (Morales et al. 2006). From these three sequences, two appear to be genetically similar to NY99, showing $100 \%$ nucleotide identity and the third sequence differed by only $1 \mathrm{nt}$ from WNV detected in New York (Morales et al. 2006). Seroprevalence studies performed on wild birds confirmed WNV activity between 2004 and 2005 in four different regions of Argentina (Diaz et al. 2008) and evidence of the cocirculation of St. Louis encephalitis virus (SLEV) and WNV in equines in Santa Fe province (Tauro et al. 2012).

Culex mosquito species are the predominant vectors of WNV worldwide, but the virus can infect $\approx 75$ mosquito species (Sardelis et al. 2001, Turell et al. 2001, Goddard et al. 2002, Ebel et al. 2005, Turell et al. 2005, Kilpatrick et al. 2010) and $>300$ avian species (Komar et al. 2005, Reisen et al. 2005). The Culex pipiens complex in the Americas is composed of two main species, $C x$. quinquefasciatus Say, which is adapted to warmer climates, and $C x$. pipiens L., which is found in cooler zones. Culex pipiens has two known forms, form pipiens and form molestus, which differ broadly in behavior and physiology, most notably the capacity to diapause and the incidence of autogeny (summarized in Farajollahi et al. 2011). North American Cx. pipiens include many hybrids of the two Cx. pipiens forms (Fonseca et al. 2004, Strickman and Fonseca 2012), and at intermediate latitudes, hybridization between Cx. pipiens and Cx. quinquefasciatus is ubiquitous (Barr 1957, 1982; Farajollahi et al. 2011; Strickman and Fonseca 2012). In Argentina, Cx. quinquefasciatus occurs from the provinces of Buenos Aires and Mendoza northwards, whereas Cx. pipiens is found from Buenos Aires southwards to the Santa Cruz province, and hybrid forms have been found in the central area of the country (Brewer et al. 1987, Almiron et al. 1995, Humeres et al. 1998), although these findings are based exclusively on morphological identification and allozyme studies.

Vector competence is a measure of the intrinsic ability of an arthropod to become infected with a pathogen, support development or replication of the pathogen, and transmit the pathogen to a vertebrate host. Mosquito populations possess inherent differences in their ability to serve as vectors in arbovirus transmission cycles (Gubler and Rosen 1976, Jupp and Kemp 1993, Kramer et al. 1993, Vaidyanathan and Scott 2007). The vector competence of Culex spp mosquitoes most likely to be involved in WNV transmission in Argentina is still unknown. The purpose of the current study was to analyze the competence of $C x$. pipiens complex mosquitoes from Argentina to begin to determine their potential importance in WNV transmission in Argentina. 


\section{Materials and Methods}

\section{Identification of Mosquitoes for Colonies}

Specimens of Culex spp. were collected as egg rafts from different habitats such as drainage ditches and artificial containers in the suburbs of La Plata city, Buenos Aires province, Argentina, during February 2012. Egg rafts were individually hatched in tap water supplemented with finely ground guinea pig food, and reared up to the pupae stage at $26^{\circ}$ with a photoperiod of 12:12 (L:D) h cycle in the insectary of CEPAVE (UNLPCONICET), Argentina. The fourth-instar larval exuviae were separated to assess the siphonal index (S.I.) (Brogdon 1981, 1984) under stereoscopic microscope. Pupae originally identified as $C x$. quinquefasciatus (S.I. values of $\leq 3.40$ ) and those belonging to $C x$. pipiens (S.I values of $\geq 4.30$ ) were placed in two different cages. Emerged adults were sugar-fed for $4 \mathrm{~d}$ and then were blood fed to obtain eggs. Egg masses from each colony were shipped to the Arbovirus Laboratories, Wadsworth Center, NY, where two separate colonies were established. To confirm morphological identifications, genomic DNA was obtained from five individual mosquitoes and 8-10 groups of 10 individuals each, from each colony via phenol or chloroform extraction as described by Fonseca et al. (2000) followed by polymerase chain reaction (PCR) amplification of the AceII gene and CQ11 locus using the protocols developed by Smith and Fonseca (2004) and Bahnck and Fonseca (2006). These DNA-based based rapid assays produce bands of varying sizes that are taxa specific. Hybrids will show a combination of bands from different taxa.

Mosquito rearing followed standard protocols (Gerberg et al. 1994). Cx. pipiens and Cx. quinquefasciatus from long-term colonies maintained in the insectary at Wadsworth Center, NY State Department of Health, Albany, NY, were used as controls in each vector competence experiment. All colonies were maintained with water pads and sugar cubes in 30 by 30 by $30 \mathrm{~cm}$ cages and held at $26^{\circ} \mathrm{C}$ and a photoperiod of $16: 8$ (L:D) h.

Field Surveys of Argentine Cx. pipiens Complex Populations. Immature stages of Culex mosquitoes were collected from three additional drainage ditches (Fig. 1, sites A, B, and C) located in the suburbs of La Plata city and Berisso city, Argentina, to determine the diversity of Culex mosquito species breeding in this area. In this geographical region, the climate is temperate (annual average temperature, from 13 to $17^{\circ} \mathrm{C}$ ), with rainfall occurring throughout the entire year (Cabrera and Willink 1980).

Larvae from each site were transported to the insectary where they were separately reared at $26^{\circ} \mathrm{C}$ in trays of $\approx 300$ larvae per tray, containing tap water and finely ground guinea pig food. Pupae were placed in three different cages ( 30 by 30 by $30 \mathrm{~cm}$ ), one per site, for adult emergence. Twenty individual adult mosquitoes emerging from the collected immatures from each of the habitats were taken at random. These 60 mosquitoes were identified with appropriate taxonomic keys (Darsie and Mitchell 1985) using male genitalia morphology and morphometry (DV/D ratio and siphonal index; Brogdon 1981, 1984; Vinogradova 2003). Three mosquitoes from each site were also analyzed with the rapid PCR-based assays, and a subset of 22 specimens ( 12 from site A and 10 from site C) was genotyped with a microsatellite panel (see below for details).

\section{Genotype Analysis}

We used a panel of eight microsatellite loci that amplify consistently across all United States Cx. pipiens complex populations (CQ11, CQ26, CxqGT4, CxqGT6b, CxpGT4, CxpGT9, CxpGT12, CxpGT46, [Smith et al. 2005]). These same loci have been used in multiple studies of populations of the Cx. pipiens complex in the United States, Western Europe, northern Africa, the Middle East, Asia, and Australia (Fonseca et al. 2004, 2009; Gomes et 
al. 2009; Strickman and Fonseca 2012) and therefore allow for broad comparisons. We examined the genetic ancestry of 22 specimens, 12 from La Plata and 10 from Berisso City. Microsatellite loci were amplified and sized as described in Smith et al. (2005). We assigned individuals to clusters (taxa) based on their multilocus genotypes with a maximum likelihood algorithm implemented in the program Structure 2.0 (Pritchard et al. 2000). We used 100,000 burn-in steps and 1,000,000 runs with a model of uncorrelated allele frequencies allowing admixture. In this analysis, the origin of each specimen is not disclosed, but the number of clusters $(\mathrm{K})$ is decided a priori for each run. To assess the consistency of the analysis, we performed an exhaustive comparison of 10 runs scoring the similarity coefficient described in Rosenberg et al. (2002). We chose the most appropriate putative number of clusters $(\mathrm{K}=3)$, by choosing the $\mathrm{K}$ with the highest associated $\Delta \mathrm{K}$ (Evanno et al. 2005). To examine the ancestry of the Argentine populations, we included in the analysis several other populations: 1) specimens of $C x$. pipiens $\mathrm{f}$. molestus collected as larvae in midwinter in Philadelphia, PA, and Germany (specimens from these populations were brought to the laboratory, and all adult females were autogenous); 2) specimens of $C x$. pipiens f. pipiens collected in Germany and the United Kingdom; and 3) specimens identified as Cx. quinquefasciatus from Florida and Louisiana (Fonseca et al. 2006).

\section{Vector Competence Assays}

Peroral Infection-These studies were conducted in the BSL3 insectary at the Arbovirus Laboratory, Wadsworth Center, NY State Department of Health. Vector competence assays were conducted using NY99 and WN02 genotype strains of WNV from New York (strain designations are NY99-3356 and WN02-1956). Bloodmeals containing virus were prepared using frozen virus stock in the first experiment and freshly harvested virus in the second. In the first assay, $8.5 \mathrm{ml}$ of defibrinated bovine blood, $0.5 \mathrm{ml}$ of $2.5 \%$ (wt:vol) sucrose, and 1.0 $\mathrm{ml}$ of frozen virus stock were mixed. In the second, confluent C6/36 cell monolayers in 75$\mathrm{cm}^{2}$ flasks were infected at an MOI of 0.1 and incubated at $28^{\circ} \mathrm{C}$ for $2-4 \mathrm{~d}$. The bloodmeal was prepared by scraping infected cells into the media and mixing the suspension 1:1 with defibrinated bovine blood and $2.5 \%$ (wt:vol) sucrose.

Five- to seven-day-old female adult mosquitoes were allowed to feed on the infected bloodmeal in sausage casing for $1 \mathrm{hr}$ at room temperature following the protocol of Ebel et al. (2004). Blood suspensions were frozen at $-80^{\circ} \mathrm{C}$ for subsequent plaque assay to determine the virus titer at the time of mosquito feeding. Females that fully engorged were separated and held in $0.47-\mathrm{L}$ cartons at $26^{\circ} \mathrm{C}$, under a photoperiod of $16: 8(\mathrm{~L}: \mathrm{D}) \mathrm{h}$, and provided a $10 \%$ sucrose solution ad libitum on cotton wicks until dissection. After 5, 7, 9, and $14 \mathrm{~d}$ after feeding on the frozen virus bloodmeal, and 7, 14, and $21 \mathrm{~d}$ for fresh virus bloodmeal, females were anesthetized with Triethylamine (Sigma, St. Louis, MO) and bodies, legs, and salivary secretions were obtained from each individual mosquito and processed as previously described (Ebel et al. 2004) to determine infection, dissemination, and transmission rates, respectively.

Peroral infection and transmission of WNV genotype NY99 and WN02 were evaluated in Cx. pipiens f.molestus from Argentina and Cx. quinquefasciatus from Argentina and United States using frozen virus; and in a second set of experiments, both species of mosquitoes from Argentina and United States were evaluated using freshly harvested virus, genotype NY99.

Vertical Transmission-Female Cx. pipiens f. moles-tus (Argentina) were offered a bloodmeal containing $8.5 \mathrm{ml}$ of defibrinated bovine blood, $0.5 \mathrm{ml}$ of $2.5 \%$ (wt:vol) sucrose, and $1.0 \mathrm{ml}$ of frozen virus stock, genotype NY99. We used this genotype of WNV because it is phylogenetically close to the sequences of WNV isolated from horses in Argentina. Fully 
engorged female mosquitoes were removed to a 1-liter carton and held for $4 \mathrm{~d}$ under the same conditions described above, after which, they were provided a dish with water for oviposition. The dead adults were collected every day and frozen at $-80^{\circ} \mathrm{C}$ until assayed for virus. The number of infected adults was evaluated by plaque assay. Eggs rafts were hatched individually in plastic cups at $27^{\circ} \mathrm{C}$, and larvae were reared in groups of $10-30$ per plastic rearing container at $27^{\circ} \mathrm{C}$ until they reached the fourth instar. These larvae were pooled in groups of 20 , frozen at $-80^{\circ} \mathrm{C}$, and processed for virus isolation in Vero cells to determine whether vertical transmission had occurred. After laying eggs, females were fed again using uninfected blood ( $9.5 \mathrm{ml}$ bovine blood with $0.5 \mathrm{ml} 50 \%$ sucrose). After feeding, a dish with water was introduced into the carton for oviposition. A second uninfected bloodmeal was offered, and mosquitoes were allowed to lay eggs again. Eggs were collected, larvae were reared, and the progeny from the second and third oviposition were processed as described.

Larval pools were ground in $1.0 \mathrm{ml}$ of mosquito diluent $(20 \%$ heat-inactivated fetal bovine serum [FBS] in Dulbecco's phosphate-buffered saline plus $50 \mu \mathrm{g} / \mathrm{ml}$ of penicillin/ streptomycin, $50 \mu \mathrm{g} / \mathrm{ml}$ of gentamicin, and $2.5 \mu \mathrm{g} / \mathrm{ml}$ of fungizone) using stainless steel BB's (Daisy Brand, UT) in a mixer mill and centrifuged at 2,500 rpm. Plaque assays were conducted as described in Payne et al. (2006).

\section{Statistical Analysis}

The number of mosquitoes with virus in legs (dissemination) and salivary secretion (transmission) was calculated as a proportion of the number of mosquitoes that developed body infection. The proportion of infected individuals obtained at the end of the experiment was compared between groups using $\chi^{2}$ or Fisher's exact tests, as appropriate according to the sample sizes. If significant differences were observed, pair-wise comparisons using Fisher's exact test were applied, with Bonferroni correction as adjustment for multiple tests. The proportions of mosquitoes infected with fresh virus were compared with those infected with frozen virus using the same statistical analyses described previously. All analyses were performed using InfoStat version 2011 (Di Rienzo et al. 2010).

\section{Results}

\section{Identification of Mosquitoes}

Mosquitoes from Argentina instead Mosquitoes for Colonies-The separation of the F1 Cx. quinquefasciatus from $C x$. pipiens was originally made based on the siphonal index, as described in Materials and Methods. After the larvae were received in the United States, the two populations from Argentina were maintained separately in the insectary, and the F2 were identified with rapid assays, as described earlier. One colony was predominantly $C x$. pipiens $\mathrm{f}$. molestus although a few mosquitoes exhibited $C x$. quinquefasciatus signatures, and the other was predominantly $C x$. quinquefasciatus with some mosquitoes also having $C x$. pipiens $f$. molestus signature. No bands diagnostic of $C x$. pipiens f. pipiens were obtained. Progeny from F3-F4 of these populations were used for vector competence studies within the first 2 mo of colonization. Because specimens with hybrid signatures were present, neither colony was composed strictly of members of one of the taxa. However, the colony that was morphologically predominantly $C x$. pipiens f. molestus was and remained autogenous, a trait usually associated with $C x$. pipiens f.molestus, whilethepredominantlyCx.quinquefasciatus colony never displayed this trait. For simplicity, we will refer to the $C x$. pipiens $\mathrm{f}$. molestus/hybrid colony as $C x$. pipiens $\mathrm{f}$. molestus, and the $C x$. quinquefasciatus/hybrid colony as $C x$. quinquefasciatus. 
Field Surveys of Argentine Cx. pipiens Complex Populations

$C x$. pipiens f. molestus, $C x$. quinquefasciatus, and hybrid populations between these two species were detected in each of the three breeding sites located in suburban La Plata city and Berisso city, Buenos Aires, Argentina (Fig. 1). These sites were artificial drainage ditches with organically polluted water. At sites A ( $\left.34^{\circ} 51^{\prime} 56^{\prime \prime} \mathrm{S}, 58^{\circ} 2^{\prime} 1^{\prime \prime} \mathrm{W}\right)$ and B ( $34^{\circ}$ $54^{\prime} 59^{\prime \prime} \mathrm{S}, 58^{\circ} 0^{\prime} 18^{\prime \prime} \mathrm{W}$ ), we detected a high degree of hybridization and a preponderance of ancestry from $C x$. pipiens $\mathrm{f}$. molestus. At site $\mathrm{C}\left(34^{\circ} 52^{\prime} 12^{\prime \prime} \mathrm{S}, 57^{\circ} 53^{\prime} 30^{\prime \prime}\right)$, there were several specimens with an apparent pure $C x$. quinquefasciatus signature although hybrids were also abundant (Fig. 2).

\section{Vector Competence Assays}

Peroral Transmission. Cx. pipiens f. molestus from Argentina (AR) (Frozen

Virus)-The percent of the population of Cx. pipiens f. molestus females (AR) that became infected with WNV after feeding on infectious blood containing $1.9 \times 10^{8} \mathrm{PFU} / \mathrm{ml} \mathrm{NY99-}$

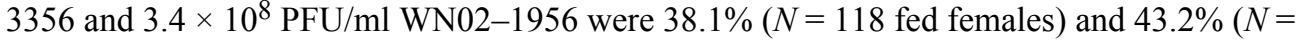
111 fed females), respectively. Infection rates with the two viral genotypes were not significantly different $\left(\chi^{2}: 0.62 ; \mathrm{df}=1 ; P=0.43\right)$. Dissemination was detected in $31.1 \%(N$ $=45)$ and $12.5 \%(N=48)$ of the infected females from Argentina for NY99 and WN02, respectively. Dissemination of virus varied from $6.7 \%(3 / 45)$ of the females that were infected by genotype NY99 on day 5 postinfection (pi), 2.2\% (1/ 45) on day 7, 20\% (9/45) on day 9 , and $2.2 \%(1 / 45)$ on day 14 . Dissemination of WNV genotype WN02 varied from $0 \%(0 / 48)$ on day $5,4.2 \%(2 / 48)$ on day $7,2.1 \%(1 / 48)$ on day 9 , and $6.25 \%(3 / 48)$ on day 14. Virus was detected in the salivary secretions of $8.8 \%(N=45)$ of infected females infected by NY99 strain. Horizontal transmission of NY99 varied from $2.2 \%(1 / 45)$ on day 5 pi to $4.4 \%(2 / 45)$ on day 9 pi and $2.2 \%(1 / 45)$ on day 14 pi while no transmission was detected with WN02. Significant differences between the two strains of virus in overall rate of dissemination $\left(\chi^{2}: 4.7 ; \mathrm{df}=1 ; P=0.02\right)$ and transmission (Irwin-Fisher bilateral: $0.54, \mathrm{df}$ $=1, P=0.05)$ were detected.

Cx. quinquefasciatus AR and the United States (Frozen Virus)-In total, 51.6\% of 93 female $C x$. quinquefasciatus AR that fed on $6.2 \times 10^{7} \mathrm{PFU} / \mathrm{ml}$ of WNV NY99-3356 were infected as compared with $95.5 \%(N=113)$ of $C x$. quinquefasciatus (United States) that ingested blood containing the same strain of virus. Dissemination (virus-positive legs) of this strain of virus was detected in 27.1\% (13/48) of the infected females from Argentina. In mosquitoes positive on day $5 \mathrm{pi}, 15.4 \%$ of the legs were infected, $38.5 \%$ at day $7 \mathrm{pi}$, and $23 \%$ at day 9 and 14 pi (Fig. 3). In the U.S. colony, overall $47.2 \%(51 / 108)$ of the legs were infected, increasing from $7.8 \%$ at day 5 pi to $56.9 \%$ on day 14 pi out of the total number of infected mosquitoes (51) (Fig. 3). Virus was detected in the salivary secretions of $16.7 \%(N$ $=48)$ of infected females from Argentina and 29.6\% $(N=108)$ from the United States, increasing from $12.5 \%$ day 5 to $37.5 \%$ day 9 pi (AR mosquitoes) and from $3.12 \%$ day 5 pi to $75 \%$ day 14 pi (U.S. mosquitoes) (Fig. 3).

When the female mosquitoes ingested blood containing $6.4 \times 10^{7} \mathrm{PFU} / \mathrm{ml}$ WNV WN02$1956,17.8 \%(N=123)$ of individuals from Argentina became infected, $27.3 \%$ of which had disseminated virus and $9.1 \%(N=22)$ transmitted virus on days 9 and 14 pi (Fig. 3). For the U.S. colony, $51.3 \%(N=117)$ were infected while $25 \%(N=60)$ and $15 \%(N=60)$ of these infected females also had a disseminated infection and transmitted the virus from day 7 to 14 (Fig. 3).

Significant differences were detected in the overall rate of transmission between the two virus genotypes when mosquitoes from Argentina and United States were infected per os $\left(\chi^{2}: 8.42 ; \mathrm{df}=3 ; P=0.038\right)$. However, pair-wise comparisons between groups (AR NY99, 
U.S. NY99, AR WN02, and U.S. WN02) using Fisher's exact test with Bonferroni correction did not show significant differences. significant differences in overall rate of infection were detected in the two virus strains between both colonies of mosquitoes $\left(\chi^{2}\right.$ : $143.43 ; \mathrm{df}=3 ; P<0.0001$ ), with significantly higher levels of infection and dissemination detected in $C x$. quinquefasciatus from the United States infected by the strain NY99-3356.

\section{Cx. quinquefasciatus and Cx. pipiens f. molestus $A R$ and the United States} using Fresh Virus-The total percent of $C x$. pipiens f. molestus females that became infected with WNV after feeding on blood containing NY99-3356 (titer: $8.8 \times 10^{7} \mathrm{PFU} / \mathrm{ml}$ ) was $30.9 \%$ of 126 fed females from Argentina and $69.4 \%$ of 36 fed females from the United States. The rates of dissemination and transmission in mosquitoes from Argentina was 64\% $(N=39)$ and $38.4 \%(N=39)$, respectively, with percentages increasing from day 7 to 21 while for U.S. mosquitoes, $88 \%(N=25)$ had disseminated infection and $40 \%(N=25)$ had detectable virus in salivary secretions, from day 7 to 14 (Fig. 4). The percent infected of $C x$. quinquefasciatus (AR) was $4.3 \%(N=115)$ after feeding on $8.8 \times 10^{7} \mathrm{PFU} / \mathrm{ml}$ of NY99, of which $40 \%(N=5)$ were able to support dissemination and transmission of the virus. The mosquitoes from United States had a $86.8 \%(N=114)$ infection rate, of which $76.7 \%$ had a disseminated infection and $66.6 \%(N=99)$ had virus-positive salivary secretions from day 7 to 21, with variable daily rates (Fig. 4). The infection rate in $C x$. quinquefasciatus AR was significantly different from $C x$. quinquefasciatus United States and also from $C x$. pipiens $\mathrm{f}$. molestus (AR and the United States) $\left(\chi^{2}: 177.2 ; \mathrm{df}=3 ; P<0.0001\right)$, although no differences were detected between both species from the United States (Fig. 5). The low number of infected individuals of $C x$. quinquefasciatus AR was insufficient for statistical analysis of dissemination and transmission rates. Despite these significant differences, there were no detectable differences in dissemination rates of this virus between both $C x$. pipiens $\mathrm{f}$. molestus AR and the United States, and $C x$. quinquefasciatus U.S. group $\left(\chi^{2}: 4.93 ; \mathrm{df}=2 ; P\right.$ $=0.085$ ). Similar transmission rates were observed in $C x$. pipiens $\mathrm{f}$. molestus AR and the United States, and they were significantly different than what was observed in $C x$. quinquefasciatus United States ( $\left.\chi^{2}: 12.03 ; \mathrm{df}=2 ; P=0.002\right)$ (Fig. 5).

Mosquito Infections with Fresh and Frozen WNV NY99. Cx. pipiens f. molestus females (AR) that became infected with fresh WNV after feeding on blood containing genotype NY99 (titer: $8.8 \times 10^{7} \mathrm{PFU} / \mathrm{ml}$ ) was compared with mosquitoes infected with frozen WNV after feeding on infectious blood containing $1.9 \times 10^{8} \mathrm{PFU} / \mathrm{ml}$ genotype NY99. No differences were detected in infection $\left(\chi^{2}: 1.37 ; \mathrm{df}=1 ; P=0.24\right)$ and transmission rates (Irwin-Fisher bilateral: $0.27, \mathrm{df}=1, P=0.15$ ) although significantly higher proportion of dissemination was detected in mosquitoes infected with fresh virus $\left(\chi^{2}: 4.82 ; \mathrm{df}=1 ; P=\right.$ $0.02)$.

Cx. quinquefasciatus AR that fed on $6.2 \times 10^{7} \mathrm{PFU} / \mathrm{ml}$ of frozen WNV genotype NY99 demonstrated a significantly higher proportion of infected individuals than those infected with $8.8 \times 10^{7} \mathrm{PFU} / \mathrm{ml}$ of fresh virus $\left(\chi^{2}: 40.46\right.$; $\left.\mathrm{df}=1 ; P<0.0001\right)$, but no differences were detected in dissemination (Irwin-Fisher bilateral: $-0.01, \mathrm{df}=1, P>0.99$ ) or transmission rates (Irwin-Fisher bilateral: $0.04, \mathrm{df}=1, P>0.99)$. For $C x$. quinquefasciatus United States, significantly higher rates of body $\left(\chi^{2}: 5.36 ; \mathrm{df}=1 ; P=0.02\right), \operatorname{leg}\left(\chi^{2}: 7.44 ; \mathrm{df}=1 ; P=\right.$ $0.006)$, and saliva infections $\left(\chi^{2}: 15.42 ; \mathrm{df}=1 ; P=0.0001\right)$ with frozen virus were detected.

Vertical Transmission. Cx. pipiens f. molestus AR-The proportion of mosquito adults infected was $65.7 \%$ (69 infected of 105 adults tested) feeding on $6.8 \times 10^{8} \mathrm{PFU} / \mathrm{ml}$ NY99 virus. After the first uninfected bloodmeal, 24 rafts with 1,200 larvae (60 pools of 20 larvae each one) were obtained with one pool positive for WNV (first or second oviposition). From the second uninfected bloodmeal, 2 pools out of 18 were positive for WNV (total of 9 rafts, 360 larvae). The third uninfected bloodmeal yielded no positive 
larvae from a single pool from $1 \mathrm{raft}, 20$ larvae. The minimum filial infection rate (MFIR), that is, the minimum number of mosquitoes infected with WNV per 1,000 offspring, was 1.9 .

\section{Discussion}

We collected and identified by morphological and molecular methods Culex mosquitoes from the suburbs of La Plata city, Argentina, and found heterogeneous populations composed of $C x$. quinquefasciatus, $C x$. pipiens $\mathrm{f}$. molestus, and hybrids resulting in a complex epidemiological situation for arbovirus transmission. No pure $C x$. pipiens $\mathrm{f}$. pipiens were collected, nor were hybrids with $C x$. pipiens $\mathrm{f}$. pipiens diagnostic signatures found. Our results indicate that $C x$. quinquefasciatus and $C x$. pipiens $\mathrm{f}$. molestus from temperate Argentina are competent but only moderately efficient vectors for WNV. They are less susceptible to this virus compared with the same mosquito species from the United States. $C x$. quinquefasciatus AR had lower infection rates than the same species from the United States for both WNV genotype WN02 and NY99. Cx. pipiens f. molestus AR had also lower infection rates than U.S for WNVNY99 although similar transmission rates were observed. Therefore, even though both Culex species are thought to contribute to WNV transmission in Argentina, at least this population of $C x$. quinquefasciatus could be considered an inefficient laboratory vector of the virus strains tested.

In our study, we tested two strains of WNV, NY99 and WN02. The nucleotide sequences isolated from horses in Argentina appear to be very closely related to NY99 strain in lineage 1A (Morales et al. 2006); however, the original NY99 genotype of WNV was displaced by the genotype WN02 throughout the United Stated by 2004 (Ebel et al. 2004, Davis et al. 2005). WN02 virus strains, compared with NY99 strains, infected a larger proportion of $C x$. pipiens and Culex tarsalis and had shorter extrinsic incubation periods (Ebel et al. 2004, Moudy et al. 2007). However, it is interesting that $C x$. quinquefasciatus did not demonstrate this trait (Vanlandingham et al. 2008). In our assay, similar rates of transmission were observed between both strains of virus for Cx. quinquefasciatus United States and AR, although the United States mosquitoes were also more susceptible to infection by the NY99 strain compared with WN02 strain. Cx. pipiens f. molestus AR demonstrated similar rates of infection for both strains of virus.

Significantly fewer $C x$. quinquefasciatus mosquitoes from Argentina became infected using freshly harvested virus of strain NY99 than U.S. mosquitoes. The ability to transmit the virus was similar between Cx. pipiens f. molestus United States and AR, but $100 \%$ of the infected U.S. species transmitted $7 \mathrm{~d}$ earlier than the AR species. The highest level of transmission was observed in Cx. quinquefasciatus United States. Vertical transmission of WNV has been reported for several species of Culex in the United States (Baqar et al. 1993; Miller et al. 2000; Nasci et al. 2001; Dohm et al. 2002; Goddard et al. 2003; Anderson and Main 2006; Phillips and Christensen 2006; Reisen et al. 2006; Anderson et al. 2008, 2012). In our experiments, the MFIR for $C x$. pipiens $\mathrm{f}$. molestus was 1.19 from eggs laid during the second and later ovipositions. An MFIR of 1.9/1,000 is equal to the estimated rate in California for Cx. pipiens complex mosquitoes of 2.0/1,000 (Fechter-Leggett et al. 2012). Our results indicate that this mosquito species in Argentina could potentially contribute to WNV persistence through the winter by vertical transmission if they were to become infected. However, because $C x$. pipiens f. molestus are autogenous and generally feed on mammals in subsequent bloodmeals (Farajollahi et al. 2011), it is unlikely they would become infected unless they contributed this trait to a hybrid population.

Cx. quinquefasciatus and Cx. pipiens are common mosquitoes that lay eggs in artificial containers (Almiron and Brewer 1996, Garcia et al., 2002) and drainage ditches (Campos et 
al. 1993) in urban and suburban areas in Argentina. These species are numerous in locations where there are avian hosts, humans and horses. They feed primarily on birds, but also will feed on mammals and humans (Almiron and Brewer 1995). However, natural feeding patterns of these species of mosquitoes in Argentina have not been studied. Both mosquito species and intermediate forms were found in Buenos Aires province, but southward only Cx. pipiens has been recorded (Almiron 1995, Rossi and Vezzani 2011). Previously, no information was available about the existence of any biotypes or forms of $C x$. pipiens in Argentina. Surprisingly, in this study, we were able to identify only $C x$. pipiens f. molestus in the study area, as well as $C x$. quinquefasciatus and hybrid populations between $C x$. quinquefasciatus and $C x$. pipiens $\mathrm{f}$. molestus. This is in keeping with a recent report (Antunes De Morais et al. 2010) that hybrid forms between $C x$. quinquefasciatus and $C x$. pipiens occur in regions of latitudes around $34-35^{\circ} \mathrm{S}$, suggesting that La Plata, Buenos Aires province, is a hybrid region. Diez et al. (2012) also extend the distribution of hybrids of $C x$. pipiens complex in Argentina from latitudes $30^{\circ} 36^{\prime} \mathrm{S}$ to $36^{\circ} 13^{\prime} \mathrm{S}$ and between longitudes $57^{\circ} 57^{\prime} \mathrm{W}$ and $64^{\circ} 48^{\prime} \mathrm{W}$. Future studies of distribution of both forms of $C x$. pipiens and vector competence of hybrid populations of $C x$. pipiens $\mathrm{f}$. molestus, $C x$. pipiens f. pipiens, and $C x$. quinquefasciatus in Argentina need to be conducted and bloodmeal determinations made to examine host feeding preferences of hybrids.

The presence of WNV competent vectors together with the known circulation of this virus in Argentina (Morales et al. 2006, Diaz et al. 2008, Tauro et al. 2012) is a cause for concern. Knowledge of vector competence, distribution, seasonal abundance, and natural feeding patterns of these vectors can help improve arbovirus surveillance and mosquito control efforts in Argentina.

\section{Acknowledgments}

We thank Pam Chin for rearing the colonized mosquitoes used in these studies and George Condon for performing the microsatellite genotyping. We also appreciate the support of the Fulbright Visiting Scholar Program, Consejo Nacional de Investigaciones Científicas y Técnicas (CONICET) and the Wadsworth Center. This study was partially funded by National Institute of Health grant one C06 RR 17715-01 supporting the insectary where these studies were conducted.

\section{References Cited}

Anderson JF, Main AJ. Importance of vertical and horizontal transmission of West Nile virus by Culex pipiens in the northeastern United Sates. J. Infect. Dis. 2006; 194:1577-1579. [PubMed: 17083043]

Anderson JF, Main AJ, Cheng G, Ferrandino FJ, Fikrig E. Horizontal and vertical transmission of West Nile Virus genotype NY99 by Culex salinarius and genotypes NY99 and WN02 by Culex tarsalis. Am. J. Trop. Med. Hyg. 2012; 86:134-139. [PubMed: 22232464]

Anderson JF, Main AJ, Delroux K, Fikrig E. Extrinsic incubation periods for horizontal and vertical transmission of West Nile virus by Culex pipiens pipiens (Diptera: Culicidae). J. Med. Entomol. 2008; 45:445-451. [PubMed: 18533438]

Antunes De Morais S, Moratore C, Suesdek L, Toledo Marrelli M. Genetic-morphometric variation in Culex quinquefasciatus from Brazil and La Plata, Argentina. Mem. Inst. Oswaldo Cruz. 2010; 105:672-676. [PubMed: 20835615]

Almiron WR, Brewer MM. Preferencia de hospedadores de Culicidae (Diptera) recolectados en el centro de Argentina. Rev. Sau de Publica. 1995; 29:108-114.

Almiron WR, Brewer MM. Classification of inmature stage habitats of Culicidae (Diptera) collected in Córdoba, Argentina. Mem. Inst. Oswaldo Cruz. 1996; 91:1-9. [PubMed: 8734943]

Almiron WR, Humeres SG, Gardenal CN. Distribution and hybridization between Culex pipiens and Culex quinquefasciatus (Diptera: Culicidae) in Argentina. Mem. Inst. Oswaldo Cruz. 1995; 90:469473. 
Bahnck CM, Fonseca DM. Rapid assay to identify the two genetic forms of Culex (Culex) pipiens L. (Diptera: Culicidae) and hybrid populations. Am. J. Trop. Med. Hyg. 2006; 75:251-255. [PubMed: 16896127]

Baqar S, Hayes CG, Murphy JR, Watts DM. Vertical transmission of West Nile virus by Culex and Aedes species mosquitoes. Am. J. Trop. Med. Hyg. 1993; 48:757-762. [PubMed: 8333569]

Barr AR. The distribution of Culex pipiens pipiens and Culex pipiens quinquefasciatus in North America. Am. J. Trop. Med. Hyg. 1957; 6:153-165. [PubMed: 13403135]

Barr, AR. The Culex pipiens complex. In: Steiner, WWM.; Tabachnick, WJ.; Rai, KS.; Narang, S., editors. Recent developments in the genetics of insect disease vectors. Stipes; Champaign, IL: 1982. p. 551-572.

Brewer M, Buffa L, Almirón W. Culex pipiens quinquefasciatus y Culex pipiens pipiens (Diptera: Culicidae) en Córdoba, Argentina. Rev. Per. Entomol. 1987; 29:69-72.

Brogdon WG. Use of the siphonal index to separate Culex pipiens subspecies and hybrids. Mosq. Syst. 1981; 13:129-137.

Brogdon WG. The siphonal index. A method for evaluating Culex pipiens subespecies and intermediates. Mosq. Syst. 1984; 16:144-152.

Cabrera, AL.; Willink, A. Biogeografía de América Latina. O.E.A. Serie de Biología, Monografía 13. General Secretariat of the Organization of American States; Washington, DC: 1980.

Campos RE, Macia A, Garcia JJ. Fluctuaciones estacionales de culícidos (Diptera) y sus enemigos naturales en zonas urbanas de los alrededores de La Plata, Provincia de Buenos Aires. Neotrópica. 1993; 39:55-66.

(CDC) Centers for Disease Control and Prevention. West Nile virus. 2012. (http://www.cdc.gov/ ncidod/dvbid/westnile/index.htm)

Darsie RF, Mitchell CJ. The mosquitoes of Argentina. Parts I and II. Mosq. Syst. 1985; 17:163-334.

Davis CT, Ebel GD, Lanciotti RS, Brault AC, Guzman H, Siirin M, Lambert A, Parsons RE, Beasley DW, Novak RJ, et al. Phylogenetic analysis of North American West Nile virus isolates, 20012004: evidence for the emergence of a dominant genotype. Virology. 2005; 342:252-265. [PubMed: 16137736]

Di Rienzo, JA.; Casanoves, F.; Balzarini, MG.; Gonzalez, L.; Tablada, M.; Robledo, CW. Grupo InfoStat, FCA. Universidad Nacional de Córdoba; Argentina: 2010.

Diaz LA, Komar N, Visintin A, Dantur Juri MJ, Stein M, Lobo Allende R, Spinsanti L, Konigheim B, Aguilar J, Laurito M, et al. West Nile Virus in birds, Argentina. Emerg. Infect. Dis. 2008; 14:689691. [PubMed: 18394305]

Diez F, Breser VJ, Quirán EM, Rossi GC. Hybrid forms of the Culexpipiens (Diptera: Culicidae): new records in La Pampa province, Argentina. Check List. 2012; 8:251-253.

Dohm DJ, Sardelis MR, Turell MJ. Experimental vertical transmission of West Nile virus by Culex pipiens (Diptera: Culicidae). J. Med. Entomol. 2002; 39:640-644. [PubMed: 12144296]

Dupuis AP 2nd, Marra PP, Reitsma R, Jones MJ, Louie KL, Kramer LD. Serologic evidence for West Nile virus transmission in Puerto Rico and Cuba. Am. J. Trop. Med. Hyg. 2005; 73:474-476. [PubMed: 16103626]

Ebel GD, Carricaburu J, Young D, Bernard KA, Kramer LD. Genetic and phenotypic variation of West Nile virus in New York, 2000-2003. Am. J. Trop. Med. Hyg. 2004; 71:493-500. [PubMed: 15516648]

Ebel GD, Rochlin I, Longacker J, Kramer LD. Culex restuans (Diptera: Culicidae) relative abundance and vector competence for West Nile virus. J. Med. Entomol. 2005; 42:838-843. [PubMed: 16363169]

Evanno G, Regnaut S, Goudet J. Detecting the number of clusters of individuals using the software STRUCTURE: a simulation study. Mol. Ecol. 2005; 14:2611-2620. [PubMed: 15969739]

Farajollahi A, Fonseca DM, Kramer LD, Kilpatrick AM. "Bird biting" mosquitoes and human disease: a review of the role of Culex pipiens complex mosquitoes in epidemiology. Infect. Genet. Evol. 2011; 11:1577-1585. [PubMed: 21875691]

Fechter-Leggett E, Nelms BM, Barker CM, Reisen WK. West Nile virus cluster analysis and vertical transmission in Culex pipiens complex mosquitoes in Sacramento and Yolo Counties, California, 2011. J. Vector Ecol. 2012; 37:442-449. [PubMed: 23181869] 
Fonseca DM, Keyghobadi N, Malcolm CA, Mehmet C, Schaffner F, Mogi M, Fleischer RC, Wilkerson RC. Emerging vectors in the Culex pipiens complex. Science. 2004; 303:1535-1538. [PubMed: 15001783]

Fonseca DM, La Pointe DA, Fleischer RC. Bottlenecks and multiple introductions: population genetics of the vector of avian malaria in Hawaii. Mol. Ecol. 2000; 9:1803-1814. [PubMed: 11091316]

Fonseca DM, Smith JL, Kim HC, Mogi M. Population genetics of the mosquito Culex pipiens pallens reveals sex-linked asymmetric introgression by Culex quinquefasciatus. Infect. Genet. Evol. 2009; 9:1197-1203. [PubMed: 19584006]

Fonseca DM, Smith JL, Wilkerson RC, Fleischer RC. Pathways of expansion and multiple introductions illustrated by large genetic differentiation among worldwide populations of the southern house mosquito. Am. J. Trop. Med. Hyg. 2006; 74:284-289. [PubMed: 16474085]

Garcia, JJ.; Micieli, MV.; Achinelly, MF.; Marti, G. Establecimiento de una población de Aedes aegypti L. en La Plata, Argentina. In: Salomón, DO., editor. Actualizaciones en Artropodología Sanitaria Argentina. Serie: Enfermedades Transmisibles, RAVE. Ciudad Autónoma de Buenos Aires; Argentina: 2002. p. 149-153.

Gerberg, EJ.; Barnard, DR.; Ward, RA. Manual for mosquito rearing and experimental techniques, Bulletin No. 5. Journal of the American Mosquito Control Association; Louisiana: 1994. Procedures for laboratory rearing of specific mosquitoes; p. 23-65.

Goddard LB, Roth AE, Reisen WK, Scott TW. Vector competence of California mosquitoes for West Nile virus. Emerg. Infect. Dis. 2002; 8:1385-1391. [PubMed: 12498652]

Goddard LB, Roth AE, Reisen WK, Scott TW. Vertical transmission of West Nile virus by three California Culex (Diptera: Culicidae) species. J. Med. Entomol. 2003; 40:743-746. [PubMed: 14765647]

Gomes B, Sousa CA, Novo MT, Freitas FB, Alves R, Corte-Real AR, Salgueiro P, Donnelly MJ, Almeida AP, Pinto J. Asymmetric introgression between sympatric molestus and pipiens forms of Culex pipiens (Diptera: Culicidae) in the Comporta region, Portugal. BMC Evol. Biol. 2009; 9:262. [PubMed: 19895687]

Gubler DJ, Rosen L. Variation among Geographic Strains of Aedes albopictus in Susceptibility to Infection with Dengue Viruses. Am. J. Trop. Med. Hyg. 1976; 25:318-325. [PubMed: 1259091]

Humeres SG, Almirón WR, Sabattini MS, Gardenal CN. Estimation of genetic divergence and gene flow between Culex pipiens and Culex quinquefasciatus (Diptera: Culicidae) in Argentina. Mem. Inst. Oswaldo Cruz. 1998; 93:57-62. [PubMed: 9698844]

Jupp PG, Kemp A. The potential for dengue in South Africa: vector competence tests with dengue 1 and 2 viruses and 6 mosquito species. Trans. R. Soc. Trop. Med. Hyg. 1993; 87:639-643. [PubMed: 7905212]

Kilpatrick AM, Fonseca DM, Ebel GD, Reddy MR, Kramer LD. Spatial and temporal variation in vector competence of Culex pipiens and Cx. restuans mosquitoes for West Nile virus. Am. J. Trop. Med. Hyg. 2010; 83:607-613. [PubMed: 20810828]

Komar N, Panella NA, Langevin SA, Brault AC, Amador M, Edwards E, Owen JC. Avian hosts for West Nile virus in St. Tammany Parish, Louisiana, 2002. Am. J. Trop. Med. Hyg. 2005; 73:10311037. [PubMed: 16354808]

Kramer LD, Hardy JL, Reeves WC, Presser SB, Bowen MD, Eldridge DBF. Vector competence of selected mosquito species (Diptera; Culicidae) for California strains of Northway virus (Bunyaviridae: Bunyavirus). J. Med. Entomol. 1993; 30:607-613. [PubMed: 8099625]

Kramer LD, Li J, Shi PY. West Nile virus. Lancet Neurol. 2007; 6:171-181. [PubMed: 17239804]

Lanciotti RS, Roehrig JT, Deubel V, Smith J, Parker M, Steele K, Crise B, Volpe KE, Crabtree MB, Scherret JH, et al. Origin of the West Nile virus responsible for an outbreak of encephalitis in the northeastern United States. Science. 1999; 286:2333-2337. [PubMed: 10600742]

Miller BR, Nasci RS, Godsey MS, Savage HM, Lutwama JJ, Lanciotti RS, Peters CJ. First field evidence for natural vertical transmission of West Nile virus in Culex univittatus complex mosquitoes from Rift Valley province, Kenya. Am. J. Trop. Med. Hyg. 2000; 62:240-246. [PubMed: 10813479] 
Morales MA, Barrandeguy M, Fabbri C, Garcias JB, Visan A, Trono K, Gutierrez G, Pigretti S, Menchaca H, Garrido N, et al. West Nile virus isolation from equines in Argentina, 2006. Emerg. Infect. Dis. 2006; 12:1559-1561. [PubMed: 17176571]

Moudy RM, Meola MA, Morin LL, Ebel GD, Kramer LD. A newly emergent genotype of West Nile virus is transmitted earlier and more efficiently by Culex mosquitoes. Am. J. Trop. Med. Hyg. 2007; 77:365-370. [PubMed: 17690414]

Nasci RS, Savage HM, White DJ, Miller JR, Cropp BC, Godsey MS, Kerst AJ, Bennet P, Gottfried K, Lanciotti RS. West Nile Virus in overwintering Culex mosquitoes, New York City, 2000. Emerg. Infect. Dis. 2001; 7:742-744. [PubMed: 11585542]

Payne AF, Binduga-Gajewska I, Kauffman EB, Kramer LD. Quantitation of flaviviruses by fluorescent focus assay. J. Virol. Methods. 2006; 134:183-189. [PubMed: 16510196]

Phillips RA, Christensen K. Field-caught Culex erythrothorax larvae found naturally infected with West Nile virus in Grand County, Utah. J. Am. Mosq. Control Assoc. 2006; 22:561-562. [PubMed: 17067064]

Pritchard JK, Stephens M, Donelly P. Inference of population structure using multilocus genotype data. Genetics. 2000; 155:945-959. [PubMed: 10835412]

Reisen WK, Fang Y, Lothrop HD, Martinez VM, Wilson J, O'Connor P, Carney R, Cahoon-Young B, Shafii M, Brault AC. Overwintering of West Nile virus in southern California. J. Med. Entomol. 2006; 43:344-355. [PubMed: 16619621]

Reisen WK, Fang Y, Martinez VM. Avian host and mosquito (Diptera: Culicidae) vector competence determine the efficiency of West Nile and St. Louis encephalitis virus transmisión. J. Med. Entomol. 2005; 42:367-375. [PubMed: 15962789]

Rosenberg NA, Pritchard JK, Weber JL, Cann HM, Kidd KK, Zhivotovsky LA, Feldman MW. Genetic structure of human populations. Science. 2002; 298:2381-2385. [PubMed: 12493913]

Rossi GC, Vezzani D. An update of mosquitoes of Argentina Patagonia with new distribution region. J. Am. Mosq. Control Assoc. 2011; 27:93-98. [PubMed: 21805839]

Sardelis MR, Turell MJ, Dohm DJ, O'Guinn ML. Vector competence of selected North American Culex and Coquillletidia mosquitoes for West Nile virus. Emerg. Infect. Dis. 2001; 7:1018-1022. [PubMed: 11747732]

Smith JL, Fonseca DM. Rapid assays for identification of members of the Culex (Culex) pipiens complex, their hybrids, and other sibling species (Diptera: Culicidae). Am. J. Trop. Med. Hyg. 2004; 70:339-345. [PubMed: 15100444]

Smith JL, Keyghobadi N, Matrone MA, Escher RL, Fonseca DM. Cross-species comparison of microsatellite loci in the Culex pipiens complex and beyond. Mol. Ecol. Notes. 2005; 5:697-700.

Smithburn K, Hughes T, Burke A. A neurotropic virus isolated from the blood of a native of Uganda. Am. J. Trop. Med. Hyg. 1940; 20:471.

Strickman D, Fonseca DM. Autogeny in Culex pipiens complex mosquitoes from the San Francisco Bay Area. Am. J. Trop. Med. Hyg. 2012; 87:719-726. [PubMed: 22869630]

Tauro L, Marino B, Diaz LA, Lucca E, Gallozo D, Spinsanti L, Contigiani M. Serological detection of St. Louis encephalitis virus and West Nile virus in equines from Santa Fe, Argentina. Mem. Inst. Oswaldo Cruz. 2012; 107:553-556. [PubMed: 22666870]

Turell MJ, Dohm DJ, Sardelis MR, O'Guinn ML, Andreadis TG, Blow JA. An update on the potential of North American mosquitoes (Diptera: Culicidae) to transmit West Nile virus. J. Med. Entomol. 2005; 42:57-62. [PubMed: 15691009]

Turell MJ, O'Guinn ML, Dohm DJ, Jones JW. Vector competence of North American mosquitoes (Diptera: Culicidae) for West Nile virus. J. Med. Entomol. 2001; 38:130-134. [PubMed: 11296813]

Vaidyanathan R, Scott TW. Geographic variation in vector competence for West Nile virus in the Culex pipiens (Diptera : Culicidae) complex in California. Vector Borne Zoon. Dis. 2007; 7:193198.

Vanlandingham DL, McGee CE, Klingler KA, Galbraith SE, Barrett AD, Higgs S. Short report: comparison of oral infectious dose of West Nile virus isolates representing three distinct genotypes in Culex quinquefasciatus. Am. J. Trop. Med. Hyg. 2008; 79:951-954. [PubMed: 19052310] 
Vinogradova EB. Ecophysiological and morphological variations in mosquitoes of the Culex pipiens complex (Diptera: Culicidae). Acta Soc. Zool. Bohem. 2003; 67:41-50. 

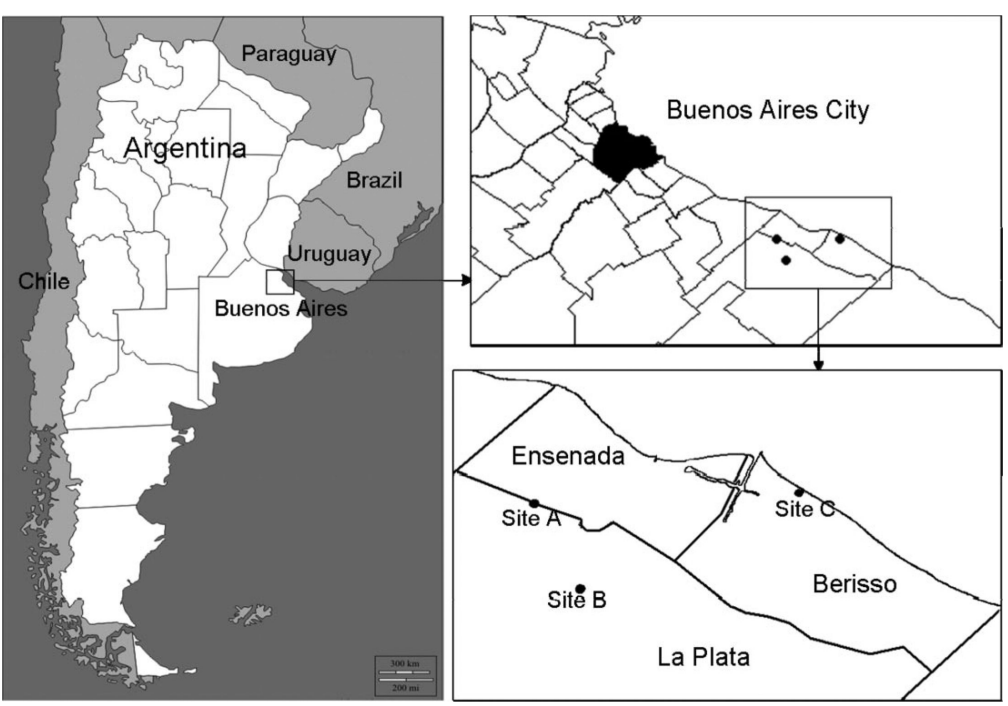

Fig. 1.

Map showing the three sampling points for Culex mosquito immature located in Buenos Aires province, Argentina. A ( $\left.34^{\circ} 51^{\prime} 56^{\prime \prime} \mathrm{S}, 58^{\circ} 2^{\prime} 1^{\prime \prime} \mathrm{W}\right)$, B ( $\left.34^{\circ} 54^{\prime} 59^{\prime \prime} \mathrm{S}, 58^{\circ} 0^{\prime} 18^{\prime \prime} \mathrm{W}\right)$, and $\mathrm{C}\left(34^{\circ} 52^{\prime} 12^{\prime \prime} \mathrm{S}, 57^{\circ} 53^{\prime} 30^{\prime \prime}\right)$. 


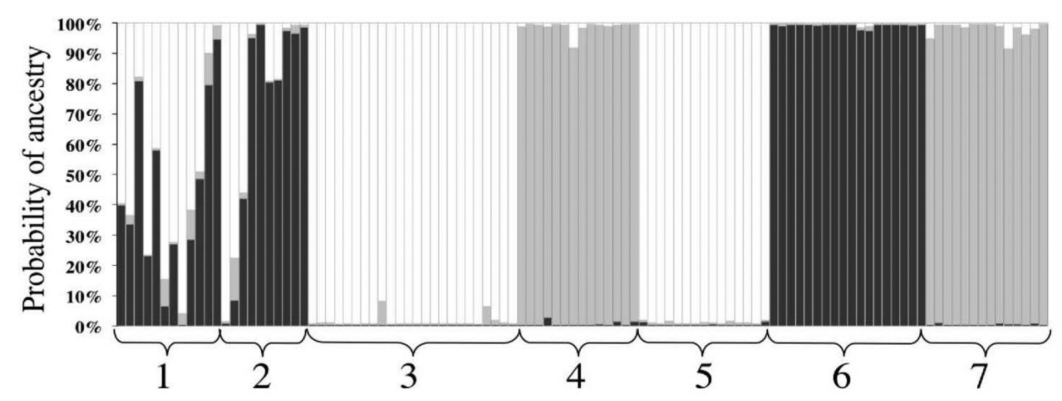

Fig. 2.

Multilocus genotype analysis of 22 specimens from Argentina based on eight microsatellite loci ( 2 females and 10 males from site A in Fig. 1, and 5 females and 5 males from site C).

These are populations 1 and 2, respectively. For comparison, we also included specimens of Cx. pipiens form molestus from Germany and from Philadelphia (24 and 15 specimens, respectively, populations 3 and 5), Cx. pipiens form pipiens from Menstrie, Scotland, and Cambridge, United Kingdom (14 of each, population 4 and 7), and Cx. quinquefasciatus from Florida and Louisiana (nine of each; population 6). Each of the individuals included in the analysis is represented by a thin vertical line, partitioned into colored segments that represent the individual's probability of belonging to one of each of the genetic clusters (genetic ancestry, in the y-axis). Although the origin of each specimen is not used in the analysis, in this figure specimens were grouped by location. 

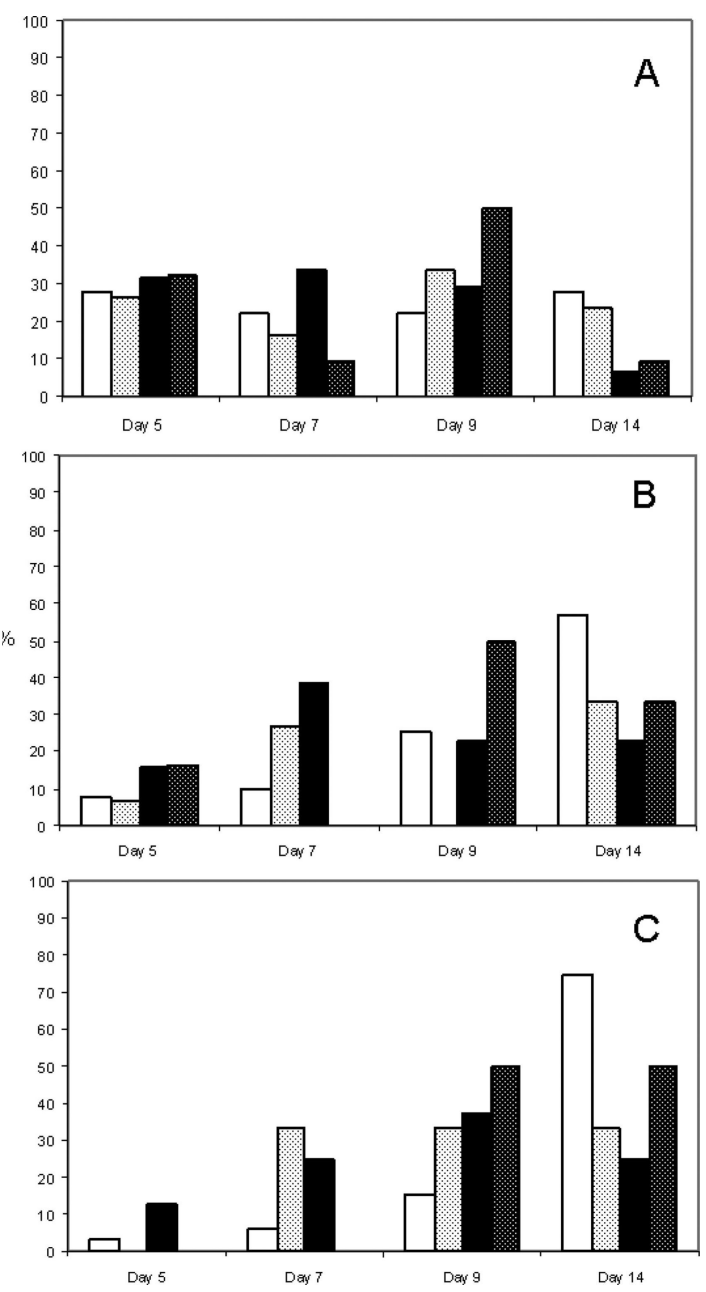

Fig. 3.

Infection, dissemination, and transmission rates per day post-infection for $C x$. quinquefasciatus orally exposed to

WestNilevirus(FrozenVirus).D5,7,9,14ratesarepercentages of mosquitoes containing virus in their bodies (A), legs (B), and saliva (C). 口U.S. Cx. quinquefasciatus-NY99, $\square$ AR Cx.quinquefasciatus-NY99, $\square$ U.S. Cx. quinquefasciatus-WN02, $\square$ AR Cx. quinquefasciatusWN02. 

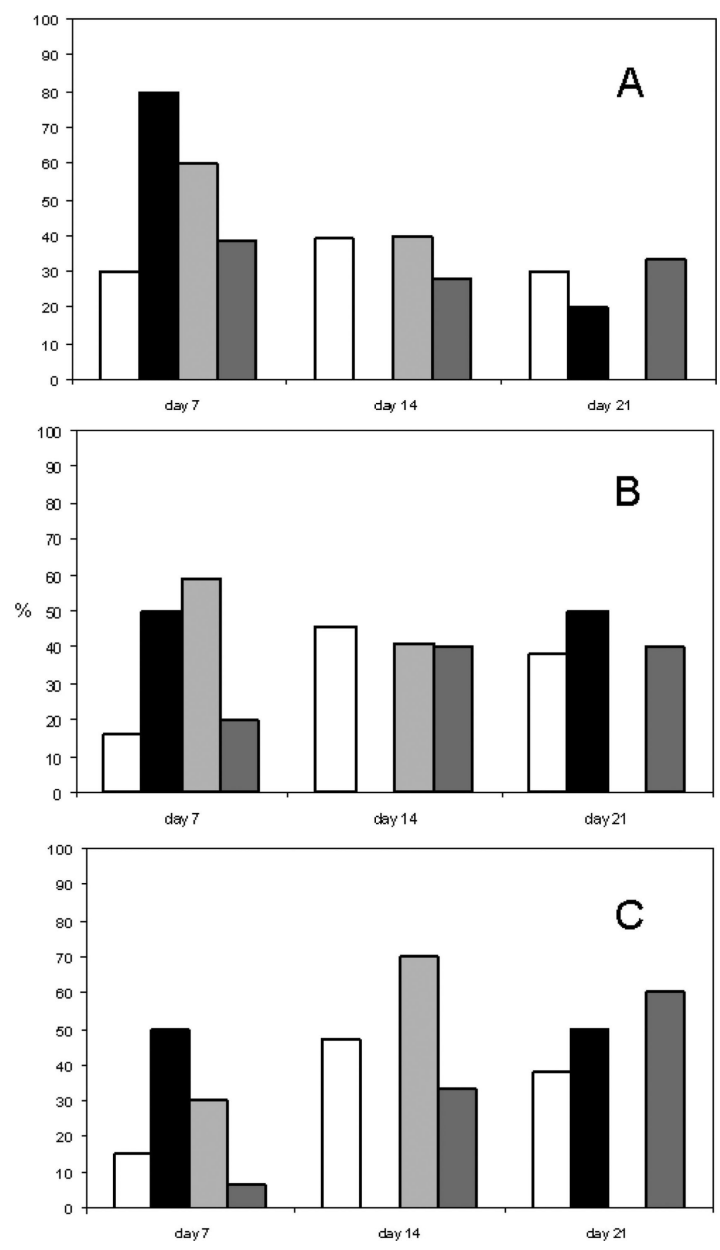

Fig. 4.

Infection, dissemination, and transmission rates per day post-infection for mosquitoes orally exposed to West Nile virus genotype NY99 (Fresh Virus). D7, 14, and 21 rates are percentages of adults with infected bodies (A), infected mosquitoes with virus in legs (B), and infected mosquitoes with virus in saliva (C) for each mosquito species. $\square$ U.S. $C x$. quinquefasciatus, $\square$ AR $C x$. quinquefasciatus, $\square$ U.S. Cx. pipiens form molestus, $\square$ AR $C x$. pipiens form molestus 


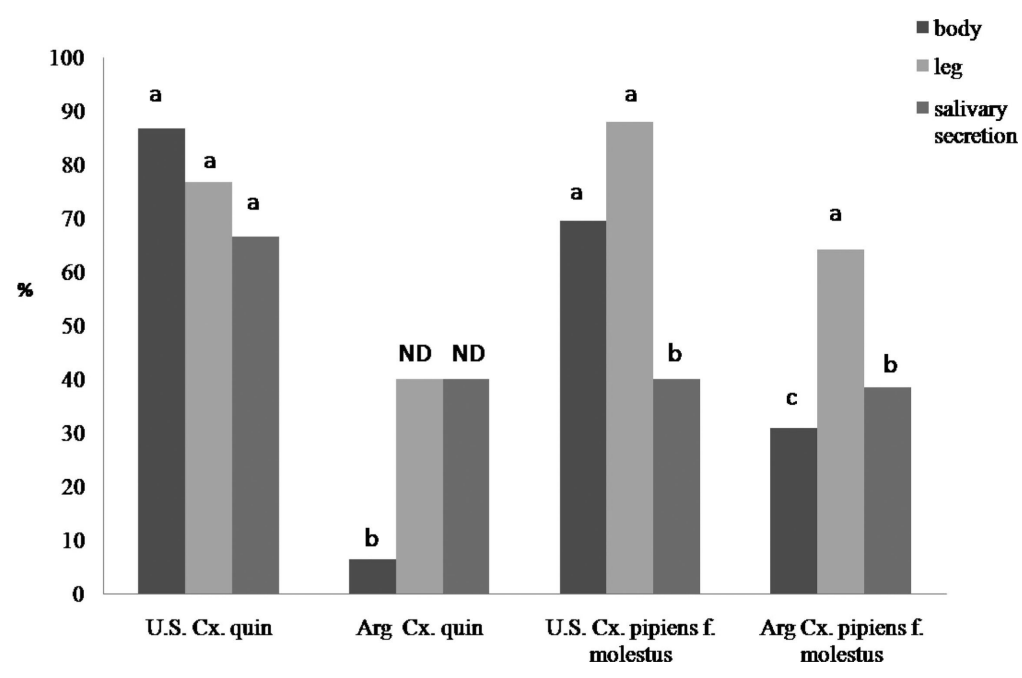

Fig. 5.

Infection (body), dissemination (leg), and transmission (sal) rates for mosquitoes orally exposed to West Nile virus genotype NY99 (fresh virus) $21 \mathrm{~d}$ postinfection. Values followed by a common letter are not significantly different by $\chi^{2}$ analysis $(P>0.05)$. U.S. Cx. quin, colonized Cx. quinquefasciatus from the United States; Arg Cx. quin, Cx. quinquefasciatus from Argentine population; U.S. Cx. pipiens f. molestus, colonized $C x$. pipiens form molestus from United States; Arg Cx. pipiens f. molestus, Cx.pipiens form molestus from Argentine population. 